\title{
SUBROGATION, PRIORITY DISPUTES AND RECTIFICATION: MAPPING A ROUTE THROUGH THE THICKET
}

\author{
STEPHEN WATTERSON ${ }^{*}$
}

\begin{abstract}
This article examines the operation of subrogation within the registered title system established by the Land Registration Act 2002 ('LRA 2002'), focusing on the concept of subrogation to another's extinguished rights. Its working premise is that two guiding principles should shape the law's development in this area. Such subrogation entitlements should arise and operate within the LRA 2002 's registered title system in a manner which is consistent with how they arise and operate more generally, outside the LRA 2002 setting. As importantly, they should also arise and operate in a manner which is compatible with, and does not undermine, the LRA 2002's framework and its underpinning policies. Although neither the courts nor the Land Registry have necessarily infringed either principle, there is a real risk that they may do so, if some troublesome lines of analysis are given unwarranted credence. This article seeks to chart a course through the thicket that can avoid such pitfalls.
\end{abstract}

\section{A. INTRODUCTION}

This article examines the operation of subrogation within a registered title system, focusing on the concept of subrogation to another's extinguished rights. ${ }^{1}$ It therefore concerns a substantial body of authorities that exhibit the following general pattern: (1) C-claimant is responsible for discharging a liability owed by D-debtor to Xcreditor; and (2) C-claimant is held to be "subrogated" to X-creditor's rights against D-debtor, including any security that X-creditor held for D's debt. Commonly, C is a disappointed lender, who advanced money to finance a property purchase or refinance existing borrowing, but failed to obtain security of the nature that it required as a condition for its advance. To rescue itself from this dilemma, $\mathrm{C}$ may argue that it is entitled in equity, by "subrogation", to security equivalent to that previously held by $\mathrm{X}$, the earlier creditor paid off via C's advance.

The English courts have proved remarkably generous in assisting $\mathrm{C}$ in such circumstances. Previously, the courts might invoke a presumption that $\mathrm{C}$ intended to "keep alive" the prior security interest for its own benefit. ${ }^{2}$ However, the landmark decision in the Banque Financière case ${ }^{3}$ has brought a revolution in our understanding. This new orthodoxy holds that such subrogation is a restitutionary remedy, afforded to reverse the unjust enrichment that would otherwise result, at C's expense, to D-debtor and others from the release of X-creditor's security.

\footnotetext{
${ }^{*}$ University Lecturer in Law, University of Cambridge; John Collier Fellow in Law, Trinity Hall, Cambridge. I am very grateful to Amy Goymour for her valuable comments on earlier drafts. All errors are my own.

${ }^{1}$ See C Mitchell and S Watterson, Subrogation: Law and Practice (OUP, Oxford, 2007) ch 1 (hereafter "Mitchell and Watterson").

2 eg Ghana Commercial Bank v Chandiram [1960] AC 732 (PC).

${ }^{3}$ Banque Financière de la Cité v Parc (Battersea) Ltd [1999] 1 AC 221 (HL); and see now, Menelaou v Bank of Cyprus (UK) Ltd [2015] UKSC 66; [2016] AC 176.
} 
This article seeks to shed further light on the operation of such subrogation entitlements within a registered title system, and in particular, the system created by the Land Registration Act 2002 ("LRA 2002"). What exactly does C acquire, when subrogated to a paid-off creditor's security interest? And, parasitic on the answer to that question, how are priority disputes involving such subrogation entitlements resolved? Although these are general questions, they present peculiar problems within registered title systems. This article's working premise is that two guiding principles should shape the law's development. Subrogation entitlements must arise and operate within the LRA 2002 system in a manner which is: (1) consistent with how they arise and operate more generally, outside the LRA 2002 setting; and which is (2) compatible with, and does not undermine, the LRA 2002's framework and its underpinning policies.

Have the courts or the Land Registry infringed either principle? Not necessarily, but there are risks that they might, if some troublesome lines of analysis are given unwarranted credence. This article attempts to chart a course through the thicket that can avoid these pitfalls. To that end, it examines four key questions:

(1) How far would the recognition of subrogation entitlements subvert the LRA 2002's underlying policies?

(2) What is the nature of the entitlement that $\mathrm{C}$ acquires, if $\mathrm{C}$ is subrogated to a paid-off creditor's security interest?

(3) How are priority disputes between a subrogation entitlement and third party interests to be resolved?

(4) What is the role for alteration/rectification of the Land Register, in the process of effectuating subrogation entitlements?

\section{B. WILL SUBROGATION SUBVERT THE LRA 2002'S FRAMEWORK?}

\section{Two potential pitfalls}

Subrogation might be accused of subverting the LRA 2002's framework or underlying policies in two key ways.

\section{(a) Undermining the LRA 2002's ordering of competing interests}

The first problem is general. It exists to the extent that subrogation entitlements arise and operate in a manner that undermines the LRA 2002's ordering of competing interests affecting registered titles. Subrogation affords $\mathrm{C}$ rights affecting a registered title, in the nature of a security interest, by operation of law. This is not necessarily incompatible with the LRA 2002's framework. Nevertheless, problems would arise if these rights bound third parties in circumstances that unjustifiably undermined the "priority promise" of LRA 2002, section 29-whereby prior rights affecting a registered title, which are neither entered in the Register nor "overriding interests", are postponed to a registered disposition made for valuable consideration. The extent of this risk depends upon the basis on which priority disputes involving subrogation entitlements are resolved.

\footnotetext{
${ }^{4}$ For this terminology, see A Goymour, "Resolving the Tension Between the Land Registration Act's 'Priority' and 'Alteration' Provisions” [2015] Conv 253, 254.
} 


\section{(b) Rescuing parties from non-compliance with the LRA 2002's demands}

The second problem is more limited. It is potentially present if $\mathrm{C}$ invokes subrogation to relieve itself from the consequences of its own failure to do what the LRA 2002 framework requires.

This problem is most likely in a subset of defective financing transactions, where C-lender advances money to D-borrower to fund the acquisition of property or refinance existing secured borrowing, and does not obtain security of the nature bargained-for. C-lender's expectations of security may be materially disappointed for many different reasons. In almost all instances, ${ }^{5}$ the English courts have been willing to assist C-lender, by finding that C-lender is subrogated to X-creditor's security, which was discharged using the loan-monies. However, what if C's expectations of security are disappointed because of the failure of $\mathrm{C}$ (or it agents) to take steps necessary, under the LRA 2002 framework, to ensure that $\mathrm{C}$ obtains security of the nature bargained-for?

Imagine that a charge is executed in an appropriate form by $\mathrm{D}$-registered proprietor in favour of $\mathrm{C}$-lender, but that the charge is not submitted by $\mathrm{C}$-lender for registration. This will not cause problems for $\mathrm{C}$, if circumstances do not change before the omission is noticed and registration belatedly occurs. However, what if transactions occur in the meantime, which result in third parties acquiring interests that affect D's registered title, and which (applying the LRA 2002's priority rules) have priority to C's unregistered charge. Can C argue that its failure to obtain security of the nature specified as a condition of its advance, justifies its being subrogated to $\mathrm{X}$-creditor's security, with priority to such later interests?

Anfield (UK) Ltd $v$ Bank of Scotland plc, ${ }^{6}$ raised exactly this problem. Applying the Banque Financière unjust enrichment analysis, Proudman $\mathrm{J}$ concluded that $\mathrm{C}$, the disappointed lender, could make out a subrogation claim: C's failure to register its security interest gave rise to a restitution/subrogation-triggering "failure of basis", notwithstanding that $\mathrm{C}$ had acted negligently. In isolation, this was not necessarily a false step in the judge's reasoning. Neither the LRA 2002's underlying policies, nor any other public policy, clearly requires that a "failure of basis"-caused by C's negligence, or otherwise-should automatically disqualify $\mathrm{C}$ from a subrogation remedy. The bigger problem is that Proudman J proceeded to afford C's subrogation entitlement a priority status that looks contrary to the LRA 2002's ordering of competing interests. Her decision requires extended analysis.

\section{The difficult case of Anfield (UK) Ltd $v$ Bank of Scotland ${ }^{7}$}

\section{(a) Background}

In 2006, Bank of Scotland (BOS) loaned money to D-registered proprietor, to redeem a registered charge held by Halifax Building Society, intending to obtain a new firstranking registered charge as security. BOS received an executed charge from D which

\footnotetext{
${ }^{5} \mathrm{Cf}$ where C's expectation is defeated by its failure to secure timely registration in the Company Charges Register: Burston Finance Ltd v Speirway Ltd [1974] 1 WLR 1648 (Ch); Smith (Administrator of Cosslett (Contractors) Ltd v Bridgend CBC [2001] UKHL 58; [2002] 1 AC 336; Mitchell and Watterson, [7.113-7.115].

${ }^{6}$ Anfield (UK) Ltd v Bank of Scotland plc [2010] EWHC 2375 (Ch); [2011] 1 WLR 2414.

${ }^{7}$ Ibid.
} 
was capable of being registered as a legal charge. Unfortunately, an oversight meant that BOS failed immediately to procure its registration, and its charge remained equitable. Before the error was noticed and BOS could take steps to rectify the problem, third parties had acquired competing claims to D's registered title. In 2007, LSFL was registered as proprietor of a registered legal charge; and in 2008, Anfield acquired an equitable charge via a charging order which was duly noted in the Register.

D's subsequent bankruptcy made the relative rankings of these security interests crucial. If left to rely on its unregistered equitable charge, BOS would have faced difficulties. Anfield's equitable charge might well rank after BOS's prior equitable charge (applying LRA 2002, section 28); but BOS's charge would be postponed to LSFL's subsequent registered charge (applying LRA 2002, section 29). BOS therefore argued that it was subrogated to Halifax's first-ranking registered charge and on that basis, had priority over both LSFL and Anfield. The County Court judge, in a decision upheld by Proudman J, held that BOS was entitled to this priority by subrogation. Indeed, the judge apparently proceeded to give effect to this conclusion by ordering that BOS should be registered as holder of Halifax's first-ranking registered charge, which formally remained on the Register.

The dynamics of the Anfield litigation require comment. Anfield had initiated the proceedings to establish that its equitable charge had priority over BOS's prior unregistered equitable charge. This was destined to fail: LRA 2002, section 28, would give BOS's charge priority. Nevertheless, Anfield's claim seemingly caused BOS to respond that it had priority, via subrogation, over both Anfield and LSFL. LSFL was then joined as third party. Following BOS's success in the County Court, however, only Anfield appealed. Proudman J was therefore faced with an unmeritorious appellant, and denied the benefit of argument from LSFL, the later registered chargee, who had the strongest claim to resist BOS's claim.

\section{(b) Proudman J's reasoning}

How did Proudman J reach her conclusion that BOS was subrogated to Halifax's firstranking charge? Proudman J took seriously Banque Financière's re-rationalisation of subrogation as a "restitutionary remedy" afforded by the law to reverse "unjust enrichment". As such, she explicitly justified the remedy's availability using the analytical framework and principles of the law of unjust enrichment.

Central to this exercise was Proudman J's identification of the relevant "unjust factor": a form of "failure of basis". ${ }^{8}$ She explained that:

"the factor that rendered the enrichment [...] unjust [was] the non-fulfilment of [BOS's expectation as to] the security [which had formed] the basis [of its decision to advance funds.]"9

And more fully, that:

"[t]he enrichment [was] unjust because [BOS] funded the repayment of the Halifax charge on the basis that it would obtain a legal charge. Because of the

\footnotetext{
${ }^{8}$ See esp C Mitchell, P Mitchell and S Watterson, Goff and Jones - The Law of Unjust Enrichment, 8th edn (London, Sweet \& Maxwell, 2011) ch 12 (hereafter "Goff and Jones").

${ }^{9}$ Anfield [2010] EWHC 2375 (Ch); [2011] 1 WLR 2414, [34].
} 
failure to register under the Land Registration Act it obtained only a subsequent equitable charge."10

It did not matter that the borrower had performed the terms of the bargain with the lender, as regards the execution of a valid charge in BOS's favour; ${ }^{11}$ nor that the only reason why BOS's security expectations were disappointed was BOS's negligent failure to procure registration of its security. ${ }^{12}$ A lender's negligence in relation to obtaining the hoped-for security was not, by itself, fatal:

"The court is required ... simply to look at the question of the justice of the enrichment of the defendant[;] [y] ou do not lose your right to resist an unjust enrichment gained at your expense simply because you have been careless in relation to the security." 13

A sufficient "failure of basis" was shown merely by proving that BOS did not obtain the expected security, even though this "failure" was caused by BOS's negligent conduct.

So far, Proudman J's reasoning represented a relatively orthodox application of the general law of unjust enrichment. It is generally accepted: (1) that restitution for mistake is not barred merely because the relevant mistaken belief was carelessly formed/held $;{ }^{14}$ and (2) that restitution may be available for failure of basis, even where the failure is claimant-precipitated, if the risk of failure occurring for the relevant reason was not a risk which the claimant was meant to bear. ${ }^{15}$ Were there nevertheless any special reasons why this particular form of claimant-precipitated failure should not trigger subrogation rights?

An argument along this lines was indeed presented in Anfield. Anfield argued that to allow subrogation would "subvert the policy of the 2002 Act". Proudman J thought this "boiled down to [a submission] that the Act forms some sort of conclusive code, enabling those who lend to rely on the position on the face of the [R] egister". She was emphatic in rejecting the argument:

"If that was correct, it would be difficult to claim subrogation in any case of registered land. [...] In my judgment the policy of the Act does not encroach on the principle of unjust enrichment. [...] [A]ny unfair consequences of subrogation can be dealt with by way of a defence founded on change of

\footnotetext{
${ }^{10}$ Ibid, [36].

${ }^{11}$ Ibid, [36].

${ }^{12}$ Ibid, [29]-[31], relying on statements in Banque Financière [1999] 1 AC 221 (HL).

${ }^{13}$ Ibid, [30].

${ }^{14}$ eg Kelly v Solari (1841) 9 M \& W 54; 152 ER 24; RE Jones Ltd v Waring \& Gillow Ltd [1926] AC 670 (HL) 688-689; Barclays Bank Ltd v WJ Simms Son \& Cooke (Southern) Ltd [1980] QB 677, 686687; Banque Financière [1999] 1 AC 221, 227, 235, 242-243; Dextra Bank \& Trust Co Ltd v Bank of Jamaica [2002] 1 All ER (Comm) 193 (PC), [45]. Cf HW Tang, "The Role of Negligence and NonFinancial Detriment in the Law of Unjust Enrichment" [2006] RLR 55. For earlier subrogation decisions consistent with this position: Mitchell and Watterson, [6.64].

${ }^{15}$ eg Dies $v$ British \& International Mining \& Finance Corp Ltd [1939] 1 KB 724; Rover International Ltd v Cannon Film Sales Ltd (No 3) [1989] 1 WLR 912 (CA), allowing restitution of advance payments, not construed as deposits, made by a claimant whose breach of contract precipitates termination of the contract by the other contracting party. For earlier subrogation decisions consistent with this position: Mitchell and Watterson, [6.87-6.90].
} 
position. This is quite different from the cases about moneylenders where subrogation was denied on public policy grounds[.]"16

This reasoning needs careful unpacking.

\section{(c) Would subrogation subvert the policies of the LRA 2002?}

When determining whether subrogation would subvert the LRA 2002 in Anfield-like circumstances, two questions must be kept separate.

The first question is whether there is any necessary incompatibility between the LRA 2002 framework and subrogation rights, such that a lender should never be afforded subrogation rights where its expectations of security are disappointed. Authority and principle suggest there is no such necessary incompatibility. It is not even obvious that C's own negligent failure to protect its interest, as in Anfield, should automatically prevent $\mathrm{C}$ establishing subrogation rights, based upon its disappointed expectations of security; the contrary view seems unjustifiably penal in effect.

The second question is whether subrogation rights are being recognised in a manner which is inconsistent with the LRA 2002, and in particular, which fails to respect the LRA 2002's mandated priority-ordering. This is the real worry raised by Anfield. The main objection was not that the facts should not have triggered subrogation rights at all, but that BOS was claiming an unjustified priority for them, given the registered land context. BOS wished to be subrogated to Halifax's firstranking registered charge, to achieve priority over competing interests subsequently acquired by LSFL and Anfield. Priority over Anfield is readily justified. But $L S F L-$ as a later registered chargee-arguably stood in a different position. Unfortunately, Proudman J's failure to analyse the applicable priority principles yielded a conclusion that, if generalised, seriously threatens the integrity of LRA 2002 regime.

\section{(i) BOS's position without subrogation}

BOS's unregistered charge was an equitable charge. As it was not protected by any entry in the Register at the relevant times, the interests of BOS, LSFL and Anfield would rank as follows:

(i) LSFL's registered charge;

(ii) BOS's unregistered, equitable charge;

(iii) Anfield's equitable charge.

Section 29, LRA 2002 would give LSFL's registered charge priority over BOS's charge. In contrast, BOS's charge would have priority over Anfield's later equitable charge via section 28 LRA 2002's first-in-time rule.

(ii) BOS's position assuming subrogation: (1) conventional analysis

How might subrogation change matters? This is where there is a risk of error, if the the rights afforded via subrogation are not well-understood.

${ }^{16}$ Anfield [2010] EWHC 2375 (Ch); [2011] 1 WLR 2414, [38]. 
The best view ${ }^{17}$ is that where $\mathrm{C}$ is subrogated to $\mathrm{X}$ 's security interest, $\mathrm{C}$ is not entitled to X's security interest, by transfer or otherwise. Rather, $\mathrm{C}$ acquires new rights in equity, which presumptively replicate X's rights, as a mechanism for reversing the unjust enrichment that would otherwise accrue to $\mathrm{D}$ (the discharged debtor) and relevant others (typically, existing junior creditors and other subordinate incumbrancers) from their release from $\mathrm{X}$ 's rights. ${ }^{18}$ It is controversial whether $\mathrm{C}$ immediately acquires an equitable replica of X's security interest, or whether D and others merely become liable in equity to be subject, via a later court order, to legal relations mirroring those that previously existed. ${ }^{19}$ Either way, $\mathrm{C}$ typically acquires an equitable entitlement in rem, from the time of the subrogation-justifying facts, whose capacity to affect later parties turns on the priority principles that generally determine the priority-ordering of interests of the relevant kind, in the relevant subject-matter.

In any particular case, this conventional approach requires careful identification of the point in time at which C's entitlement first arose. In Anfield, this was not precisely analysed by Proudman J. Assuming that C's entitlement would date from the point when the subrogation-justifying "failure of basis" occurred, there are two major possibilities, consistent with Proudman J's characterisation of the "unjust factor" in play. ${ }^{20}$ Whichever is assumed, the conventional approach suggests that BOS should not obviously have been any better off via subrogation.

$i$. Early failure, owing to non-registration of BOS's charge. The first possibility is that the "failure" occurred at an early stage, simply because of BOS's failure to procure registration of its charge, shortly after it had been executed - an omission which rendered its security, as an unregistered equitable charge, susceptible to future subordination on later dispositions of the affected title by the registered proprietor. Even if, from that time, BOS was entitled in equity to a security interest replicating Halifax's security interest, BOS would be no better off. The LRA 2002's priority provisions would arguably yield the same priority-ranking:

(i) LSFL's registered charge;

(ii) BOS's subrogation-based equitable charge;

(iii) Anfield's equitable charge.

For priority purposes, BOS's subrogation-based charge would rank as a new equitable entitlement, dating from the subrogation-justifying facts. This interest, not being protected by any relevant entry in the Register, would be postponed via section 29 , LRA 2002 to LSFL's later registered charge. However, being earlier in time, it would retain priority via section 28, LRA 2002 over Anfield's later equitable charge.

ii. Later failure, on later subordination of BOS's charge. The second possibility is that the "failure" only occurred at a subsequent stage, when that risk became a reality - when LSFL obtained a registered charge which took priority to BOS's stillunregistered charge as a result of section 29, LRA 2002. In this case, the conventional approach might look even more adverse to BOS; if BOS's subrogation entitlement only arose on LSFL's later acquisition of a superior charge, then it might appear to post-date LSFL's interest - even if only by a split second. LSFL's interest might then take priority in any event under section 28 LRA 2002's first-in-time rule.

\footnotetext{
${ }^{17}$ See infra, Part C(1).

${ }^{18}$ See esp Day v Tiuta International Ltd [2014] EWCA Civ 1246, [43]; Mitchell and Watterson, ch 8.

${ }^{19}$ See infra, Part C(1)(c)(i).

${ }^{20}$ See supra, text at nn 8-15.
} 
Proudman J reached a different conclusion. She seemed to assume that if BOS was subrogated to Halifax's first-ranking charge, then BOS would necessarily have priority to Anfield's equitable charge and to LSFL's registered charge. ${ }^{21}$ This is difficult to comprehend, for three reasons - even on the view most favourable to BOS, that it acquired a subrogation entitlement that pre-dated LSFL's charge.

First, her conclusions are hard to square with the LRA 2002's priority provisions and with section 29's "priority promise". Even if BOS's subrogation entitlement did pre-date LSFL's charge, ${ }^{22}$ LSFL could rely on section 29 to establish priority for its subsequent registered charge over any competing earlier interest, unless that earlier interest was an overriding interest or entered in the Register at the relevant time. BOS's subrogation-based entitlement was not an overriding interest. Nor was it protected by entry in the Register. At best, all that relevantly appeared in the Register when LSFL registered its charge was Halifax's still-registered charge - an empty shell ${ }^{23}$ that fortuitously remained only because BOS had failed to procure its removal and replacement with BOS's newly-registered charge. Prima facie, therefore, there was no basis within the terms of section 29 for preserving the priority of BOS's subrogation-based entitlement over LSFL's registered charge.

Second, Proudman J's general understanding of subrogation, unless treated with caution, risks subverting the LRA 2002 framework. A subrogation claimant should not obtain priority over later interests merely because it has been responsible for discharging an earlier, first-ranking registered charge. Priority should only be afforded insofar as the LRA 2002 framework allows for it. Otherwise, the LRA 2002's "priority promise", and the ability of later parties to rely on the Register, could be unjustifiably undermined. Anfield's counsel raised exactly this objection. ${ }^{24}$ Unfortunately, the problem which Anfield faced was that the LRA 2002 framework does not embody any universal policy of the sort argued for. Only a subset, albeit a large subset, of parties are currently peculiarly favoured: those, like LSFL, who acquire an interest under a registered disposition for valuable consideration, and can rely on section 29, LRA 2002 to establish priority over earlier interests. Otherwise, the logic of the LRA 2002's priority provisions is that later parties like Anfield act at their peril: an earlier unprotected interest, not visible from the Register, prevails.

Third, although there are ways of explaining Proudman J's conclusion that LSFL's registered charge was subject to BOS's subrogation entitlement, despite the apparent effect of section 29, LRA 2002, each raises difficulties.

$i$. The absence of prejudice, given Halifax's subsisting registered charge. One gut instinct response is that LSFL suffered no real prejudice on the facts. When LSFL acquired its registered charge, a Register search would have revealed Halifax's stillregistered charge. In truth, Halifax's charge was an empty shell. Nevertheless, if LSFL was willing to take what appeared to be a second-ranking charge, ranking after Halifax's charge, what injustice would be caused by holding LSFL bound by BOS's subrogation-based entitlement, even if it was not discoverable in the Register? LSFL could not have thought that D-borrower had an unencumbered title. Unfortunately, gut instincts do not, without more, constitute a basis for principled judicial

\footnotetext{
${ }^{21}$ Anfield [2010] EWHC 2375 (Ch); [2011] 1 WLR 2414.

${ }^{22}$ See supra, text following n 20.

${ }^{23}$ The liabilities owed to Halifax were discharged; there was no outstanding liability owed to Halifax which the charge secured.

${ }^{24}$ See supra, Part B(2)(b), text following n 15.
} 
determinations. Indeed, the assumption that LSFL was not prejudiced might not be correct. LSFL might have inquired of Halifax/the registered proprietor as to the outstanding indebtedness secured by Halifax's subsisting charge, and been given the answer that there was none.

ii. Parasitic protection for BOS's claim, via Halifax's subsisting registered charge. A second explanation achieves at least formal consistency with the LRA 2002 framework. On this view, BOS's subrogation-based entitlement would not be postponed to LSFL's registered charge via section 29 LRA 2002, because the priority of BOS's interest would be deemed to be protected by an entry in the Register in respect of Halifax's subsisting registered charge - a "parasitic" form of priority protection. In Bank of Scotland plc v Joseph ${ }^{25}$ the Court of Appeal recently held that a notice which a lender had entered in respect of an equitable charge could preserve the priority of the subrogation-based entitlement that arose as a result of the charge's invalidity. However, an equivalent argument in Anfield requires a greater leap of reasoning. The existing protective entry would be in the name of a different party (Halifax) from that of the subrogation claimant (BOS).

iii. Subrogation operates via exact replication of the paid-off creditor's priority position. A third explanation involves an unconventional analysis of how subrogation work, whereby $\mathrm{C}$ steps into $\mathrm{X}$-creditor's shoes in all respects. Accordingly, if $\mathrm{C}$ discharges X-creditor's first-ranking registered legal charge, $\mathrm{C}$ occupies exactly the same position via subrogation. C's priority position vis-à-vis subsequent incumbrancers is determined as if $C$ had a pre-existing first-ranking registered legal charge. C's subrogation-based entitlement then necessarily prevails over all later parties. Proudman J's decision may implicitly involve such a premise. She suggested that "[i]ntermediate lenders are necessarily enriched by the discharge of a prior security", ${ }^{26}$ implying an assumption that C's priority vis-à-vis those parties is necessary to prevent/reverse their unjust enrichment. Put differently, the implicit assumption might be that:

(i) if X's charge had subsisted, the third parties would have been affected by it;

(ii) the discharge of X's charge has accordingly "enriched" them, insofar as they are not bound by an interest that would otherwise have affected them;

(iii) to prevent/reverse that "enrichment", C's subrogation-based charge must have exactly the same priority as X's charge would otherwise have had.

There are two possible responses. First, on conventional accounts, subrogation does not work like this. Subrogation-generating facts trigger an immediate equitable replica of X's charge, or a liability in equity to be subject by court order to such a charge. This is the law's response to the enrichment that immediately results from the "unjust release" of X's charge, to D (the discharged debtor) and relevant others (existing junior incumbrancers). However, C's position vis-à-vis subsequent incumbrancers is resolved on the different basis, that $\mathrm{C}$ has an pre-existing equitable entitlement in rem, whose priority is determined on conventional principles. Second, this unconventional analysis threatens the LRA 2002's mandated priority-ordering. Following the analysis

\footnotetext{
${ }^{25}$ Bank of Scotland plc v Joseph [2014] EWCA Civ 28; [2014] 1 P\&CR 18.

${ }^{26}$ Anfield [2010] EWHC 2375 (Ch); [2011] 1 WLR 2414, [11].
} 
to its logical conclusion, if C discharged X's registered charge, a party in LSFL's position might be affected by C's subrogation-based charge even though, when it acquired its own registered charge, there was no entry affecting the registered title, in favour of either $\mathrm{C}$ or X. That is hard to defend.

iv. Subrogation affects third parties via "in personam", "direct rights". The last explanation attempts a different reconciliation with the LRA 2002. On this view, the reason why BOS could claim priority vis-à-vis LSFL was not that BOS had an entitlement in rem, affecting BOS on conventional priority principles, but that BOS could establish a direct in personam right against LSFL, to be treated as if it was the holder of Halifax's first-ranking registered charge, in order to prevent the unjust enrichment that would otherwise accrue to LSFL from the release of Halifax's security. The LRA 2002's priority provisions do not rule out in personam claims: they determine the priority ordering of in rem entitlements. Nevertheless, this analysis looks fragile. It requires an assumption that subrogation works in a dramatically in personam fashion - such that, if we wanted to ascertain whether any subsequent party, like LSFL, may be subject to BOS's subrogation claim, we would ask directly whether it is necessary to regulate BOS's position vis-à-vis that particular defendant as if BOS was effectively an assignee of Halifax's security, in order to prevent that particular defendant's unjust enrichment. However, as Part D explains, this is an unstable approach, which does not offer a tolerable explanation of how the remedy of subrogation to extinguished rights works. ${ }^{27}$ And it might not, in any event, yield the conclusion reached in Anfield. Was LSFL really unjustly enriched by the release of Halifax's security, at BOS's expense, if section 29, LRA 2002 provided for LSFL's registered charge to have priority?

\section{(d) Wider implications}

The Anfield decision involves under-analysed and arguably faulty assumptions. It reached the wrong result, or the right result by a flawed process of reasoning which, if generalised, could seriously undermine the LRA 2002's priority framework. This is not inevitable: subrogation entitlements can arise and operate consistently with the LRA 2002. Nonetheless, for this to be possible, the courts require a clear and stable understanding of the rights that subrogation affords, and of the principles that determine their priority vis-à-vis competing interests.

\section{WHAT RIGHTS DOES SUBROGATION AFFORD?}

\section{General principles}

A necessary first step for understanding how subrogation operates within the LRA 2002 setting must be to understand the rights that subrogation affords under the general law. This is often misperceived.

\section{(a) C does not actually acquire $X$-creditor's rights}

First, when $\mathrm{C}$ discharges X-creditor's security interest, in circumstances that justify $\mathrm{C}$ being subrogated to $\mathrm{X}$-creditor's rights, $\mathrm{C}$ does not obtain $\mathrm{X}$-creditor's actual rights,

\footnotetext{
${ }^{27}$ See further infra, Part D(1)(iii).
} 
or the benefit of X-creditor's actual rights, by transfer or otherwise. ${ }^{28}$ The discharge of X-creditor's rights is a pre-condition for the subrogation remedy. ${ }^{29}$ As such, "subrogation to extinguished rights" is unlike the more familiar species of subrogation, encountered in indemnity insurance, where an indemnity insurer, having indemnified its insured, is entitled to bring proceedings, in the insured's name, to enforce the insured's subsisting rights against third parties.

\section{(b) $C$ is afforded new and independent rights, replicating $X$-creditor's rights}

Second, properly understood, the subrogation remedy affords $\mathrm{C}$ new rights that prima facie replicate the characteristics and content of X-creditor's rights. Previously, courts might talk of X-creditor's security being "kept alive" in equity for C's benefit, ${ }^{30}$ or of $\mathrm{C}$ being akin to an "equitable assignee" of X-creditor's security. ${ }^{31}$ However, such statements are at best metaphors, and not literal truths. X-creditor's rights are not actually "kept alive" for C's benefit. ${ }^{32}$ Where such subrogation operates, equity operates on the facts to afford $\mathrm{C}$ new rights that prima facie replicate the rights which X-creditor previously held, against D and others, and which C's payment extinguished. ${ }^{33}$ This is a restitutionary mechanism, which reverses in specie the unjust enrichment that would otherwise result, to D and others, from the release. ${ }^{34}$

\section{(c) The quality of C's rights}

\section{(i) An equitable entitlement arising out of court}

Third, the weight of authority suggests that, from the time of the subrogationjustifying facts, $\mathrm{C}$ has an equitable entitlement, ordinarily effective in rem, even when $\mathrm{X}$-creditor's rights were legal in quality. This was a truth conveyed in older cases via the language that X-creditor's rights were "kept alive" "in equity" for C's benefit. ${ }^{35}$ If $\mathrm{C}$ discharged X's legal charge/mortgage, $\mathrm{C}$ was entitled in equity to be treated as if it occupied X's position. This did not technically mean that $\mathrm{C}$ had, or would obtain, a legal charge/mortgage. In none of the relevant cases did the court state that $\mathrm{C}$ actually had a legal charge/mortgage, or that $\mathrm{C}$ was entitled to have such security, by subrogation. Equity apparently regulated C's relations with others as if $\mathrm{C}$ had such security, even though, in truth, $\mathrm{C}$ did not. This was an oblique way of expressing the truth that $\mathrm{C}$ was afforded new rights, in equity, which replicated those previously held by $\mathrm{X}$-creditor. ${ }^{36}$

\footnotetext{
${ }^{28}$ esp Banque Financière [1999] 1 AC 221 (HL) 236-37; Filby v Mortgage Express (No 2) Ltd [2004] EWCA Civ 755; Day [2014] EWCA Civ 1246, [43].

${ }^{29}$ Boscawen v Bajwa [1996] 1 WLR 328 (CA) 340. Also Banque Financière [1999] 1 AC 221 (HL) 236.

${ }^{30}$ eg Chetwynd v Allen [1899] 1 Ch 353, 357; Butler v Rice [1910] 2 Ch 277, 282; Chandiram [1960] AC 732 (PC) 745; Western Trust \& Savings Ltd v Rock [1993] NPC 89 (CA).

31 eg Burston Finance [1974] 1 WLR 1648 (Ch) 1652; Western Trust [1993] NPC 89 (CA).

${ }^{32}$ See esp Banque Financière (n 3) 236-237.

${ }^{33}$ See esp Filby [2004] EWCA Civ 755, [63]; Day [2014] EWCA Civ 1246, [43], relying on Mitchell and Watterson, ch 8.

${ }^{34}$ See further S Watterson, "Modelling Subrogation as an "Equitable Remedy" (2016) 2(2) Canadian Journal of Comparative and Contemporary Law 609, esp Part II, unpacking the Banque Financière orthodoxy.

${ }^{35}$ See the cases cited supra, n 30.

${ }^{36}$ This is not inevitable: the law could have developed otherwise, such that $\mathrm{C}$ would/could have rights by subrogation of precisely the same quality, legal or equitable.
} 
The exact quality of C's equitable entitlement has not been well-analysed. The cases arguably waver between two models of how the subrogation remedy works. ${ }^{37}$ The strong institutional model suggests that $\mathrm{C}$ obtains a fully-formed, vested equitable replica of X-creditor's rights, independently of any court order, automatically from the time of the subrogation-justifying facts, ${ }^{38}$ or on C's exercising a "power in rem", which arose ab initio, to bring such rights into being. This has been said to follow from C's entitlement "in equity" to be treated as if it held the paid-off security. ${ }^{39}$ In contrast, the liability model assumes that a court's order is necessary for the final crystallisation of C's rights. Subrogation-justifying facts trigger a liability, on $\mathrm{D}$ and relevant others, to be subjected by court order to legal relations equivalent to those that previously existed, when this is appropriate to reverse the unjust enrichment that resulted from their release. $\mathrm{C}$ has a concomitant entitlement to bring proceedings to obtain such an order, but will not acquire enforceable replicas of X-creditor's rights until a court determination. Nevertheless, in the meantime, this liability to have the court recognise legal relations in relation to D's asset, equivalent to those that previously existed, has effect in rem, and renders C's concomitant entitlement a species of equitable in rem entitlement, insofar as it can affect third parties who subsequently acquire competing claims to the same subject-matter. ${ }^{40}$

\section{(ii) The role of the court in subrogated proceedings}

Uncertainty concerning the nature of C's pre-court entitlement is mirrored by uncertainty about the court's role in effectuating C's claim. Two types of order are routinely granted to subrogation claimants. Their effect and significance varies according to the correct model of the remedy.

First, subrogation claimants routinely obtain declaratory orders, ${ }^{41}$ which declare that they have become entitled to be subrogated to some paid-off security interest, typically dating back to the time it was discharged. The strong institutional model suggests that such orders are merely affirmatory. They are not necessary for the creation of C's rights, which pre-date any court's order. They merely confirm that C has previously become entitled in equity to rights replicating X-creditor's rights. In contrast, the liability model suggests that the court's declaration has an essential constitutive effect, in finally crystallising C's rights. It transforms C's nascent subrogation entitlement into an enforceable equivalent of X-creditor's rights. C's ultimate position should not, however, differ under the two competing models. Either immediately from the operative facts, or the court's later crystallising order, C is

\footnotetext{
${ }^{37}$ For full discussion, see generally Watterson (2016) 2(2) CJCCL 609, esp Part IV. Note the further question, inadequately addressed in the authorities, whether the nature of the entitlement that $\mathrm{C}$ acquires under either of the models discussed here is ever "power-contingent", in the sense that its existence/crystallisation/enforceability may be contingent on the exercise of some relevant power by $\mathrm{C}$ ( $e g$ to rescind a defective transaction under which money is paid, or to obtain rights to some asset consequent upon a tracing exercise): ibid, at 653-664. The answer given to this question may affect the dating of C's entitlement, and its quality - there would be stronger case for regarding C's interest, pending exercise of such a power, as a "mere equity".

${ }^{38}$ As assumed in Halifax plc $v$ Omar [2002] EWCA Civ 121; [2002] 2 P\&CR 26.

${ }^{39}$ Ibid.

${ }^{40} \mathrm{Cf}$ occasional statements that $\mathrm{C}$ has an "equity" or "equitable property right" which is "satisfied"/“enforced"/"vindicated" by the court's later "order" for subrogation: esp Boscawen [1996] 1 WLR 328 (CA) 335, 342; cf also subsequently, Omar [2002] EWCA Civ 121; [2002] 2 P\&CR 26, [81], [82]; Karasiewicz [2002] EWCA Civ 940, [19]; Day [2014] EWCA Civ 1246, [42].

${ }^{41}$ See Watterson (2016) 2(2) CJCCL 609, Part III.A and Part V.A.1.
} 
entitled in equity to be treated as if it held rights equivalent to those previously held by X-creditor.

Second, subrogation claimants also routinely seek consequential enforcement orders. ${ }^{42}$ These are conventional orders available to holders of standard security interests, according to the bundle of rights/powers conferred by security of that nature, and the ordinary mode(s) of its enforcement (eg orders for possession, the appointment of receiver, or sale). There is a consistent and uncontested practice that the orders available to subrogation claimants are those, but only those, available in respect of discharged security. This means, on the one hand, that $\mathrm{C}$ cannot assert rights/obtain an order that would not be available in respect of security of the nature discharged. For example, if $\mathrm{C}$ is subrogated to an unpaid vendor's lien, the available orders are only those ordinarily available to a lien-holder. ${ }^{43}$ On the other hand, $\mathrm{C}$ can assert rights/obtain any order that would be available in respect of security of the nature discharged, even though such a right/order may not be available as an ordinary incident of an equitable security interest. ${ }^{44}$ An equitable charge/mortgage does not characteristically bring a right to possession, enforceable out of court or by a court order for possession. Nevertheless, if C discharged another's legal charge/mortgage, which conferred such a right, $\mathrm{C}$ may be equivalently-placed, by virtue of subrogation. It is not necessary, to explain that outcome, to assume that $\mathrm{C}$ actually holds a legal charge. It is sufficient that equity would regulate C's relations, with $\mathrm{D}$ and relevant others, as if $\mathrm{C}$ had equivalent rights.

\section{The nature of subrogation rights within the LRA 2002 regime}

Must this analysis change within the LRA 2002's registered title system? It is not obvious that C's position should be any different. Nevertheless, some courts have instinctively, without discussion or argument, proceeded differently-granting orders to subrogation claimants that transform their subrogation entitlements into something that, in cases outside the LRA 2002 framework, C would not have. Is that a false step?

Imagine that X held a security interest which encumbered D's registered title, and which $\mathrm{C}$ discharged in circumstances that would justify C's being subrogated to X's position. Imagine further that X's security interest was, alternatively:

(i) an equitable charge;

(ii) a registered legal charge, which was fully paid off and removed from the Register;

(iii) a registered legal charge, which was fully paid off but formally remains on the Register; or

(iv) a registered legal charge, which was only partly paid off and formally remains on the Register.

\footnotetext{
${ }^{42}$ Ibid, Part V.A.2.

${ }^{43}$ eg Thurstan v Nottingam Permanent Building Society [1902] 1 Ch 1 (CA) 14 (Romer LJ) ("The defendant society, having only an equitable charge, was not entitled to take possession of the mortgaged property. The proper remedy of the society was to obtain a receiver.”).

${ }^{44}$ eg Western Trust [1993] NPC 89 (CA); Piddington (1995) 70 P\&CR 592 (CA); Halifax Mortgage Services Ltd v Muirhead (1998) 78 P\&CR 418 (CA); Karasiewicz [2002] EWCA Civ 940; UCB Group Ltd v Hedworth (No 2) [2003] EWCA Civ 1717; [2003] 3 FCR 739. Each of these cases seems to manifest an unexamined assumption that C-lender, being subrogated to an earlier paid-off legal charge, was entitled to an order for possession (subject to the normal restrictions).
} 
Does the quality of C's subrogation entitlement vary as between these four situations? In particular, in cases (ii), (iii) or (iv), will C's entitlement encompass an entitlement to a registered (legal) charge? Three different analysis vie for recognition.

\section{(a) C can never become a new registered charge-holder, by subrogation}

The first analysis, most faithful to historic and modern understandings of the remedy, is that C's entitlement is the same in every case. Regardless of whether X's interest was an equitable charge or a registered legal charge, and, if a registered legal charge, whether it has been removed from the Register, or formally remains, the nature of C's entitlement is the same. C is not entitled to X's actual rights, or the benefit of X's actual rights: the very assumption on which $\mathrm{C}$ becomes entitled to the subrogation remedy is that these rights have, so far as relevant, been extinguished. Instead, by virtue of equity's operation on the facts, or a court's subsequent crystallising order, C acquires a new and independent equitable security interest, which prima facie replicates that previously held by $\mathrm{X}$. This reflects the basic premise on which the subrogation remedy is understood to operate: $\mathrm{C}$ is entitled in equity to be treated as if it holds a security interest which replicates the paid-off creditor's. On this view, even when X's charge was a registered legal charge, C's interest is not technically a registered charge, and $\mathrm{C}$ has no right to such a registered charge by subrogation. Furthermore, C's interest cannot be converted, by any order of the court, into such a charge - whether for the future, or a fortiori, for the past. Within the unregistered title regime, $\mathrm{C}$ would not be entitled, via subrogation, to a legal charge. The nature of C's entitlement should not be transformed, merely by its translation into the registered title/LRA 2002 regime.

Some cases nevertheless cast doubt on this understanding. Without analysis, they assume that even where $\mathrm{C}$ has fully paid off X's registered charge, the court might order that $\mathrm{C}$ be registered as proprietor of that charge. ${ }^{45}$ This has apparently occurred, without comment (1) where fortuitously, X's charge was never formally vacated from the Register; ${ }^{46}$ but also (2) where X's charge had been removed from the Register. ${ }^{47}$ One example is Castle Phillips Finance Co Ltd v Piddington, ${ }^{48}$ where C-lender was $s u b$-subrogated ${ }^{49}$ to an earlier lender's registered charge. The Court of Appeal ordered the Register to be rectified, seemingly to show $\mathrm{C}$ as proprietor of the earlier lender's registered charge, which had been vacated from the Register many years earlier. Another example is Cheltenham \& Gloucester plc $v$ Appleyard ${ }^{50}$ where C-lender, $C \& G$, was subrogated to B\&B's first registered charge, which $C \& G$ had paid off. On an application by $C \& G$ following a first instance judgment in its favour, the Registrar seems to have rectified the Register to show $C \& G$ as proprietor of the $B \& B$ charge.

These decisions look surprising. They are susceptible to two different readings.

\section{(b) C can be registered as holder of X's charge}

\footnotetext{
${ }^{45}$ Castle Philips Finance Co Ltd v Piddington (1995) 70 P\&CR 592 (CA); Cheltenham \& Gloucester plc v Appleyard [2004] EWCA Civ 291; Primlake Ltd v Matthews Associates [2009] EWHC 2776 (Ch); Anfield [2010] EWHC 2375 (Ch); [2011] 1 WLR 2414. Cf Mitchell and Watterson, [8.1138.123].

${ }^{46}$ eg Appleyard [2004] EWCA Civ 291; Anfield [2010] EWHC 2375 (Ch); [2011] 1 WLR 2414.

47 Piddington (1995) 70 P\&CR 592.

${ }^{48}$ Ibid.

${ }^{49}$ For discussion of the concept of 'sub-subrogation, see Mitchell \& Watterson, [9.16-9.17]; Watterson (2016) 2(2) CJCCL 609, Part II.E.

${ }^{50}$ Appleyard [2004] EWCA Civ 291.
} 
One analysis is that the courts really have thought that they can effectuate C's subrogation entitlement by ordering the re-registration of X's charge, in favour of $\mathrm{C}$ (if it had been vacated), or its transfer to $\mathrm{C}$ (if it subsisted). However, this would be inconsistent with the modern "orthodoxy", that $\mathrm{C}$ does not actually acquire X's rights, or the benefit of X's rights, by subrogation. The subrogation remedy does not "reverse" unjust enrichment by affording $\mathrm{C}$ the actual rights/the benefit of the actual rights that $\mathrm{X}$ has/had. As Lord Hoffmann stated in Banque Financiere, where a secured debt is repaid, "the charge is not kept alive at all ... [it] is discharged and ceases to exist". ${ }^{51}$ The subrogation remedy does not directly contradict this-literally preserving or bringing back to life X's rights. Equity affords $\mathrm{C}$ new rights, which prima facie replicate X's rghts, only to the extent that X's rights were extinguished.

Consistently with this, outside the registered title/LRA 2002 setting, a court would not have made an order that would have invested $\mathrm{C}$ with the legal mortgage/charge previously held by $\mathrm{X}^{52} \mathrm{~A}$ court would just have found that $\mathrm{C}$ was entitled in equity to be treated as if it had the rights that were discharged. Why should the court's role, and the nature of C's resulting entitlement, be transformed merely because the case arises in the registered title/LRA 2002 setting? Whatever should be occurring, it certainly should not be the registration of $\mathrm{C}$ as holder of X's registered charge. And it should not matter whether X's charge (1) had previously been removed from the Register, or (2) was fully paid off but not removed from the Register, or (3) was partly paid off and remained on the Register to secure D's outstanding liabilities to $\mathrm{X}$. In each case, the quality of C's right is the same: a new and independent right that only arises to the extent that the liabilities secured by X's charge were paid off.

\section{(c) C can become a new registered charge-holder, replicating X's charge}

A less dramatic analysis is that the courts in cases like Piddington did not really mean that $\mathrm{C}$ can be registered as proprietor of $X$ 's charge. Instead, what they actually meant was that $\mathrm{C}$ was entitled in equity to equivalent rights to those previously held by $\mathrm{X}$, and that a court could legitimately give further effect to C's entitlement, by elevating it to the formal status of a (new) registered charge. That is, a court might further effectuate C's entitlement to be treated in equity as having rights equivalent to X's, by transforming the right, at least for the future, into what, within the LRA 2002 framework, is actually a registered (legal) charge. Whilst the Land Registry might seem to record $\mathrm{C}$ as holding $X$ 's charge, this was not what was intended. It is just a misleading shorthand for the truth: $\mathrm{C}$ is entitled, by subrogation, to a new registered charge that replicates X's paid off charge.

This alternative analysis looks less obviously wrong. It merely involves the court giving full(er) effect to the entitlement that $\mathrm{C}$ is assumed to have: a new right, replicating X's. Nevertheless, there are reasons for caution.

Above all, there is little evidence that the courts did/could have achieved a similar transformation of C's rights into a real legal charge within the unregistered title system. The courts might have decided that $\mathrm{C}$ would, by subrogation, obtain a real legal charge/mortgage, or have a right to call on $\mathrm{D}$ or the court to grant $\mathrm{C}$ a legal charge/mortgage replicating X's charge. However, as already indicated, that was not the basis on which the courts appear to have proceeded. $\mathrm{C}$ was treated in equity, as if

\footnotetext{
${ }^{51}$ Banque Financière [1999] 1 AC 221 (HL) 236.

${ }^{52} \mathrm{Cf}$ the Mercantile Law Amendment Act 1856, s 5, which pre-dates modern developments, and which might work on a different premise, out of line with the wider judicially-developed law.
} 
it had an equivalent charge - a process of reasoning that assumes that $\mathrm{C}$ does not, actually. If so, and if $\mathrm{C}$ would not have - and could not ask the court to grant/order the granting of - an unregistered legal charge within the old unregistered title system, why should matters look different within the LRA 2002's registered title system? Why should the court/Land Registry be able to transform or elevate C's subrogation entitlement into something that $\mathrm{C}$ would not otherwise have - a real legal charge?

Three other points might be noted. First, it may not strictly be necessary to transform C's rights in this way. $\mathrm{C}$ is entitled in equity to be treated as if it holds a security interest that replicates the paid-off creditor's, vis-à-vis D-discharged debtor, and relevant others. Vis-à-vis those parties, C can seemingly rely on the ordinary incidents/advantages characteristic of the security interest paid off. ${ }^{53}$ If that is correct, then $\mathrm{C}$ may not suffer any significant prejudice because $\mathrm{C}$ does not technically have a registered charge. Secondly, if transformation is tolerated, there is a risk that the courts/Registry may confuse the process involved-lapsing into the flawed theory that $\mathrm{C}$ is actually taking over $\mathrm{X}$ 's rights, and deriving from that unwarranted implications. Thirdly, if C's subrogation-based entitlement is afforded the status of a registered charge - a state-guaranteed ${ }^{54}$ form of interest - it may thereby obtain greater validity than its juristic origins warrant. C's subrogation entitlement, a remedy afforded to reverse unjust enrichment, may justifiably exhibit greater fragility than a conventional, consensually-acquired charge. A preferable approach, respectful of those origins, is to accept that C's entitlement is an off-Register interest, arising by operation of law, whose priority is merely protected by a notice in the Register. Such an entry does not enhance the interest's validity: notice protection does not guarantee an interest's inherent integrity/validity. ${ }^{55}$

\section{HOW ARE PRIORITY DISPUTES RESOLVED?}

\section{The general problem}

\section{(a) Priority dimensions}

Where C discharges D's liabilities to X-creditor, which were secured by a security interest over D's title, there are three categories of third party whose status/priority vis-à-vis C's subrogation-entitlement must be understood. First, immediately before X-creditor's security interest was paid-off, and C's subrogation-entitlement arose, third parties may have held interests that also encumbered D's title: pre-existing incumbrancers. These may be other creditors with security interests, or non-creditors with another form of interest (eg a merely equitable/beneficial co-owner). Their interests may have been subject to X-creditor's security interest, or have had priority over it. Secondly, where D's liabilities to X-creditor are not completely discharged, $\mathrm{X}$-creditor remains in the picture: its original security interest will subsist as security

\footnotetext{
${ }^{53}$ See supra, Part C(1), and esp (b), and (c)(ii).

${ }^{54}$ For the distinction between "registrable interests" (whose validity is "guaranteed") and rights that are merely "recorded" in the register (whose priority is thereby protected, but whose validity is not thereby "guaranteed"), see eg Law Commission, Updating the Land Registration Act 2002 - A Consultation Paper (Law Com CP No 227, 2016), [2.27-2.31]. The nature of the "guarantee" is a function of the extent to which a registered interest is susceptible to removal/qualification by alteration/rectification of the Register (via LRA 2002, sch 4), and the availability of an indemnity for loss suffered in that event (via LRA 2002, sch 8).

${ }^{55}$ LRA 2002, s 32(3).
} 
for D's outstanding liabilities. Thirdly, other parties may acquire interests affecting D's title after X-creditor's security interest was paid off, and C's subrogationentitlement arose: subsequent incumbrancers. They may be, eg, later transferees of D's freehold or leasehold title, or lessees, or other creditors who acquire some form of security over D's title, by grant or otherwise.

\section{(b) Resolving these problems}

How are these problems resolved? Crucially, there is no single, simple answer. Each situation requires a different solution.

\section{(i) Pre-existing third party incumbrancers}

This first problem is susceptible to simplest solution, on the authorities and in principle. Where $\mathrm{C}$ discharges $\mathrm{X}$ 's security interest, in circumstances justifying the subrogation remedy, $\mathrm{C}$ is ordinarily entitled to be placed in an equivalent position, for the purpose of reversing the unjust enrichment that would otherwise arise, at that time, from the release of X's security, to D and others. As such, C is ordinarily entitled to be treated, from the time of the subrogation-justifying facts, as holding a security interest that inherits the priority-ranking of X's security vis-à-vis pre-existing incumbrances. ${ }^{56} \mathrm{C}$ 's subrogation-based security will therefore be subject to preexisting interests to which X's security was subject (eg a pre-existing first-ranking charge, where X's security was a second-ranking charge). Conversely, it will have priority to pre-existing interests that were subject to X's security (eg a pre-existing second-ranking charge which ranked behind X's first-ranking charge, or the interest of a beneficial co-owner which was subject to X's charge). This is all that the remedy's rationale requires. The release of X's security improves the position of preexisting subordinate interests - a form of a "secondary" enrichment. Affording C security with priority vis-à-vis those interests is a tailored way of reversing that unjust secondary enrichment in specie. ${ }^{57}$

\section{(ii) $X$, the paid-off creditor}

The second problem, arising where $\mathrm{X}$ creditor is only partly paid-off, needs more sensitive treatment. ${ }^{58}$ It is sometimes assumed that $\mathrm{C}$ can acquire no subrogation entitlement, or no immediately enforceable subrogation entitlement, here, at least before $\mathrm{X}$ has been fully paid. However, there is no satisfactory basis in principle for any universal proposition to that effect. Sometimes, it will be inconsistent with a contract between $\mathrm{C}$ and $\mathrm{X}$ for $\mathrm{C}$ to claim subrogation rights at least before $\mathrm{X}$ is fully paid. Otherwise, bold statements that $\mathrm{C}$ can have no subrogation rights until $\mathrm{X}$ is fully paid involve a disproportionate response to an understandable concern: that C's

\footnotetext{
${ }^{56}$ eg Mortgage Express Ltd v McDonnell [2001] EWCA Civ 887; [2002] 1 FCR 162; Karasiewicz [2002] EWCA Civ 940; Appleyard [2004] EWCA Civ 291; National Westminster Bank plc v Mayfair Estates Property Investments Ltd [2007] EWHC 287 (Ch); Kali v Chawla [2007] EWHC 2357 (Ch); [2008] BIPR 415; Barons Finance Ltd v Kensington Mortgage Co [2011] EWCA Civ 1592.

${ }^{57}$ See further Goff and Jones, [39.56], [39.13-29.15]; cf previously, Mitchell and Watterson, [8.68], [4.03-4.22].

${ }^{58}$ For full discussion of the dilemmas arising where X-creditor's secured debts are only partly discharged, see Mitchell and Watterson, [9.50-9.101], [8.80-8.89]; and more briefly, Goff \& Jones, [39.54-39.61].
} 
subrogation rights might unduly prejudice X's ability to obtain satisfaction for its outstanding claims.

If $\mathrm{C}$ indeed obtained, by subrogation, an entitlement to take over X's actual, subsisting security interest, this might seem a real risk: any attempt by $\mathrm{C}$ to enforce that security would appear necessarily to compete with, and detract from, X's enforcement ability. However, Banque Financière confirms that this is not how this species of subrogation works: $\mathrm{C}$ does not acquire X's rights, or the benefit of X's rights; $\mathrm{C}$ acquires new rights in equity to the extent that $\mathrm{X}$ 's rights have been diminished. ${ }^{59}$ As such, there is no conceptual objection to C's acquiring a security interest, by subrogation, whilst X's security interest subsists. Furthermore, C's new entitlement can be recognised in a form which does not prejudice X's position. It is only necessary to assume that $\mathrm{C}$ is entitled to a new security, which ranks immediately after X's security interest, but otherwise replicates the priority-ranking that X's interest had vis-à-vis pre-existing third party interests. There is old authority for this solution, ${ }^{60}$ but it also has the support of modern cases. ${ }^{61}$ It should, in principle, be preferred.

\section{(iii) Subsequent third party incumbrancers}

The third problem is more resistant to easy resolution. It brings the greatest potential for misunderstanding, and, depending on its solution, the greatest risk of conflict with the LRA 2002 framework. In unpacking the law's approach, one is forced to confront a basic controversy about how subrogation really works - a controversy fuelled by Lord Hoffmann's explanation for the remedy's operation in Banque Financière:

"[S]ubrogation [...] [is] an equitable remedy against a party who would otherwise be unjustly enriched. It is a means by which the court regulates the legal relationships between a plaintiff and a defendant or defendants in order to prevent unjust enrichment. When judges say that the charge is 'kept alive' for the benefit of the plaintiff, what they mean is that his legal relations with a defendant who would otherwise be unjustly enriched are regulated as if the benefit of the charge had been assigned to him. It does not [...] follow that the plaintiff must for all purposes be treated as an actual assignee of the benefit of the charge and, in particular, that he would be so treated in relation to someone who would not be unjustly enriched." 62

Assuming that subrogation is a remedy that reverses the unjust enrichment that would otherwise result from the release of another's security, what exactly does this mean? Three interpretations, with very different implications, compete for recognition.

i. An open-ended, in personam remedial inquiry. The most radical approach assumes that subrogation works in a dramatically open-ended, in personam fashion: to ascertain whether a later party is affected by C's subrogation claim, one asks directly whether, if that party were not so affected, it would be unjustly enriched at C's expense. Followed strictly, this analysis appears disturbingly unstable. C will

\footnotetext{
${ }^{59}$ See esp Banque Financière [1999] 1 AC 221 (HL) 236, per Lord Hoffmann.

${ }^{60}$ eg Chetwynd v Allen [1899] 1 Ch 353; similarly, Gedye v Matson (1858) 25 Beav 310, 312; 53 ER 655, 656, per Romilly MR.

${ }^{61}$ See esp Banque Financière [1999] 1 AC 221 (HL) 235-236, per Lord Hoffmann, and 243-245, per

Lord Hutton, where the approach adopted in Chetwynd $v$ Allen is otherwise treated as correct.

${ }^{62}$ Banque Financière [1999] 1 AC 221 (HL) 236.
} 
never acquire what is a conventional right "in rem", mirroring X's entitlement. Whether and how far $\mathrm{C}$ should be treated as equivalently-placed to $\mathrm{X}$ would fall to be decided by the answer to an open-ended, in personam inquiry: is it necessary in the circumstances to regulate C's position vis-à-vis this particular defendant, as if C were an assignee of X's security, to prevent this particular defendant's unjust enrichment? It seems very unlikely that this really was what Lord Hoffmann meant. It is inconsistent with long-standing authority and numerous post-Banque Financière cases, which proceed on the assumption that $\mathrm{C}$ acquires a real entitlement in rem, in the nature of a fully-fledged security interest, by subrogation.

ii. An entitlement in rem; complete replication of $X$ 's priority position. The second approach assumes, more conventionally, that $\mathrm{C}$ is entitled to a security interest by subrogation. However, it then also takes the bold further step of assuming that the priority position of C's interest should replicate the priority position of X's interest in all respects. As such, C's interest will not only inherit X's priority-ranking vis-à-vis pre-existing incumbrancers, which were subject to X's interest at the time of its discharge. C can also claim the same priority vis-à-vis later interests as $X$ 's interest would have had, if it had not been discharged. Followed strictly, this approach has dramatic implications. X's charge is typically a registered charge. Being registered, it would ordinarily prevail, pursuant to sections 28 and 29, LRA 2002, against any interest subsequently acquired over the relevant registered title. The logic of this second approach suggests that $\mathrm{C}$ would claim the same priority for its subrogationbased charge.

This is one way of rationalising Proudman J's approach in the Anfield case, where BOS, which was subrogated to Halifax's first-ranking registered charge, was thought to be entitled to priority vis-à-vis LSFL, a later registered charge-holder. Proudman J assumed BOS could claim the same priority as Halifax had, seemingly on the basis that, subject to LSFL showing that it suffered prejudice amounting to a change of position defence, this priority was necessary to reverse the "unjust enrichment" that would otherwise accrue to intervening incumbrancers, including LSFL, from the release of Halifax's prior charge. But for its release, Halifax's charge would have continued as a first-ranking registered charge. Any later party, including a party who, like LSFL, could rely on section 29, LRA 2002, would have been subject to it. To negate, inter alia, the advantage that LSFL would otherwise obtain, if its charge prevailed, BOS's subrogation-based charge would have exactly the same priority as Halifax's security would have had, but for its discharge.

This analysis cannot be accepted, except at the cost of subverting the LRA 2002's priority framework. Generalised, it means that $\mathrm{C}$ can assert its subrogation-based charge, which was not the subject of any entry on the Register, vis-à-vis any later party who would have been subject to X's security, if it had (fictionally) remained in existence on the Register-even though the LRA 2002's priority framework would suggest that any entitlement that $\mathrm{C}$ might have, being actually not on the Register at the relevant time, should be postponed. This would seriously undermine the Register's reliability. It is also difficult to see how this theory works, even when judged within its own terms. A third party, like LSFL, would otherwise take title clear of an interest like that of $\mathrm{C}$-which was neither entered in the Register nor an overriding interest-via section 29, LRA 2002. How can this outcome-which is specifically mandated by the LRA 2002 to ensure the reliability of the Register and the security of registered dispositions-involve an unjust enrichment to the later party? 
iii. A new equitable entitlement in rem; priorities independently determined. A third approach should ultimately prevail. It resolves C's position vis-à-vis later thirdparty incumbrancers on a more conventional, property law basis. As such, the courts should proceed on the basis that $\mathrm{C}$ acquires a new equitable entitlement in rem as the subrogation-justifying facts occur, and that the priority of that entitlement falls to be determined on that basis, according to conventional property law principles-ie, using the principles that are conventionally used to determine the relative priorities of rights of the relevant quality, affecting that particular subject-matter. This allows C's position to be ascertained on a stable basis, compatible with prevailing priority frameworks.

This third approach is the approach which is overwhelmingly supported by authority. ${ }^{63}$ There is, however, some room for disagreement about the exact nature of this equitable entitlement "in rem", reflecting a larger theoretical disagreement about the operation of the subrogation remedy, discussed above. ${ }^{64}$

One analysis, clearly evident in Halifax plc $v$ Omar, ${ }^{65}$ reflects a strong institutional model: $\mathrm{C}$ is assumed to acquire a fully-formed equitable replica of $\mathrm{X}$ 's rights from the time of the subrogation-justifying facts. On that basis, $\mathrm{C}$ is assumed to have a full equitable interest, and not anything less. In contrast, the alternative liability model assumes that as subrogation-justifying facts occur, D (the discharged debtor) and others (eg existing junior incumbrancers) only come under a liability, enforceable by $\mathrm{C}$, to be subject by court order to legal relations replicating those that previously existed. Adopting this view, a court order is necessary for the final crystallisation of that nascent entitlement into fully-formed equitable replicas of X's rights. What is C's priority position in the intervening period? The cases suggest that the liability as to the remedy exists in rem, insofar as it can affect third parties who subsequently acquire competing interests in the same subject-matter. However, the law faces a choice, as regards whether this liability in rem-and therefore C's concomitant in rem entitlement - affords $\mathrm{C}$ a full equitable interest, or only a lesser mere equity. There is no pre-ordained, logically correct answer. Happily, for the purposes of this article, any uncertainty about what model operates, and its implications, has limited importance. $\mathrm{C}$ holds either a full equitable interest or a mere equity, out of court, from the time of the subrogation-justifying facts. ${ }^{66}$ Even if C's pre-court entitlement was a mere equity, it would still qualify as an "interest capable of binding successors in title", and be subjected by the LRA 2002 to the same priority framework as a full equitable interest. ${ }^{67}$

How might this third approach work in practice?

\footnotetext{
${ }^{63}$ See esp Chandiram [1960] AC 732 (PC); Boscawen [1996] 1 WLR 328 (CA); Omar [2002] EWCA Civ 121; [2002] 2 P\&CR 26; Appleyard [2004] EWCA Civ 291, [44]; Bank of Scotland v Joseph [2014] EWCA Civ 28.

${ }^{64}$ See supra, Part C(1)(c)(i), and Watterson (2016) 2(2) CJCCL 609, esp Part IV.

${ }^{65}$ Omar [2002] EWCA Civ 121; [2002] 2 P\&CR 26.

${ }^{66}$ Note also what is said in $\mathrm{n} 37$, supra, about the under-examined possibility that the interest that $\mathrm{C}$ acquires via either model may sometimes be "power-contingent", such that its existence/crystallisation, or at least enforceability, may be contingent on the exercise of some relevant power by $\mathrm{C}$ ( $\mathrm{eg}$ to rescind a defective transaction under which money is paid, or to obtain rights consequent upon a tracing exercise). This answer given to this question may affect the dating of C's entitlement, and its qualitythere would be stronger case for regarding C's interest, pending exercise of the power, as a "mere equity".

${ }^{67}$ LRA 2002, S 116; Law Commission, Land Registration for the Twenty-First Century: A Conveyancing Revolution (Law Com No 271, 2001) [5.32-5.36].
} 


\section{Resolving disputes with subsequent interest-holders}

\section{(a) Introduction}

The parameters of the priority problems raised by subrogation claims should now be clearer. The first stage is always to ascertain whether facts have occurred that justify C's being subrogated to X's security interest. Where this is the case, C ordinarily has some species of equitable entitlement in rem, dating from the subrogation-justifying facts. The second stage is to then determine the priority implications of that startingpoint. This requires the application of conventional property law principles: identifying and applying the priority rules conventionally used to resolve a competition between interests of the relevant quality, affecting the relevant subjectmatter. Where the competing interests affect a registered title to land, the primary reference-point is the LRA 2002's priority regime, contained in sections 28 and 29. However, a closer inquiry reveals some hidden complexities.

\section{(b) Achieving priority for C's entitlement over later interests}

Applying section 28, LRA 2002, C's interest, created first in time, will presumptively prevail over any later interest. Nevertheless, C's interest is clearly vulnerable to later dealings with the registered title that attract the application of section 29, LRA 2002-namely registrable, and subsequently registered, dispositions made for valuable consideration. The activation of section 29 may lead to the postponement of C's interest to the later registered disposition. On what assumption might the priority of C's interest be protected vis-à-vis such transactions that activate section 29 ?

\section{(i) Direct protection}

$\mathrm{C}$ can certainly protect its subrogation-based interest via a notice in the Register. This should ensure priority against any later interests, including later registered dispositions of the relevant title.

Such priority is wholly consistent with the LRA 2002 framework. However, some cases go further than this, and generously permit $\mathrm{C}$ a form of parasitic priority protection. Here, C's priority is not protected by an entry specifically designed to protect the priority of C's subrogation-based interest. Instead, C's priority is protected parasitically, because it is treated as preserved vis-à-vis later registered dispositions by some other entry in the Register. ${ }^{68}$ Whether this is proper ultimately depends on whether the decision to afford C's interest priority over the third party's interest illegitimately contradicts the priority promise which the LRA 2002's main body offers via section 29. Several different forms of parasitic protection require consideration.

\section{(ii) Parasitic protection: entry of notice by $C$ in respect of defective charge}

First, $\mathrm{C}$ might enter a notice in respect of an equitable charge which $\mathrm{C}$ believed was valid, but which is actually invalid. This deficiency may in turn justify $\mathrm{C}$ being subrogated to an earlier paid-off creditor's security. Unfortunately, if unaware of the

\footnotetext{
${ }^{68}$ Joseph [2014] EWCA Civ 28; [2014] 1 P\&CR 18 (notice protecting ineffective charge). Cf Filby [2004] EWCA Civ 755 (ineffective registered charge). See further Mitchell and Watterson, [8.124$8.128]$.
} 
problem, C will not enter a notice specifically to protect the priority of its subrogation-based interest. Will it therefore be postponed to an intervening registered disposition by section 29 LRA 2002? Or can C rely on the notice entry in respect of the defective charge, to gain "parasitic" priority protection for the subrogation-based interest, which arose because of the deficiency in the charge which $\mathrm{C}$ intended that notice to protect? The Court of Appeal's recent decision in Bank of Scotland plc $v$ Joseph $^{69}$ suggests that $\mathrm{C}$ can do so. Is this justified? This reading certainly erodes the extent of the immunity afforded by section 29 LRA 2002 to registered disponees, and it subjects them to C's subrogation-based charge, without the benefit of an indemnity. But perhaps the third party cannot really complain, insofar as: (i) a Register-search would have suggested that there was a prior charge held by $\mathrm{C}$; and (ii) C's subrogation-based charge would certainly not exceed, in nature and quantum, what $\mathrm{C}$ had bargained-for and believed it had obtained.

\section{(iii) Parasitic protection: registration of a charge by $C$, which proves defective ${ }^{70}$}

Second, more commonly, $\mathrm{C}$ will obtain a registered charge which subsequently proves to be defective. If the charge had been valid, any intervening party would have taken subject to the charge by virtue of its registration. But what if the charge is invalid, in circumstances that entitle $\mathrm{C}$ to be subrogated to an earlier creditor's security. Can a later registered disponee argue that, whilst it would be subject to C's registered charge, if valid, it will take free of C's "unprotected" subrogation-based entitlement?

No case has yet directly addressed this problem, but it could have arisen in Filby $v$ Mortgage Express (No 2) Ltd. ${ }^{71} \mathrm{ME}$ advanced money to $\mathrm{Mr}$ and Mrs Filby, to discharge an existing first registered charge over their co-owned home, on the condition of its acquiring a new first registered charge. The earlier charge was discharged, and ME was registered as proprietor of a new registered charge. Later, HSBC obtained a second registered charge over the property, for the couple's valid debts. After default on ME's loan, it was realised that Mrs Filby's consent to ME's loan/charge had been forged. This could present the following conundrum. HSBC, as a later registered chargee, would take its interest subject to ME's forgery-tainted first registered charge. However, an application by Mrs Filby, to have the Register rectified to cancel ME's charge, would almost certainly succeed. The same circumstances might entitle ME to a charge by subrogation to the earlier, paid-off creditor's valid registered charge, effective against $\mathrm{Mr}$ and Mrs Filby; but this subrogation-based charge would not have been directly protected by any entry on the register when HSBC's charge was registered. Could HSBC rely on section 29, LRA 2002, to take free of ME's unprotected subrogation-based interest?

That would appear a rather unmeritorious argument. In taking its registered charge, HSBC cannot have assumed that the couple's title was unencumbered: the Register would show ME as first-ranking registered chargee. Allowing HSBC priority would look even more objectionable, if HSBC was only able to acquire its own registered charge because, without any intention to cede priority, ME had consented

\footnotetext{
${ }^{69}$ Joseph [2014] EWCA Civ 28; [2014] 1 P\&CR 18.

${ }^{70} \mathrm{Cf}$ Mitchell and Watterson, [8.124-8.128].

${ }^{71}$ Filby [2004] EWCA Civ 755.
} 
to its creation/registration. ${ }^{72}$ There are several possible ways of avoiding this unappetising conclusion. First, and most straightforwardly, the courts might allow the entry in respect of C's (here ME's) defective registered charge to afford parasitic protection to the subrogation-based right that arose because of its unknown invalidity. This would follow from Joseph, ${ }^{73}$ extended to include (defective) registered charges, and not only notices relating to (defective) equitable charges. Second, to similar general effect, the courts might adopt a principle that where a later incumbrancer would have taken subject to C's security, if valid, it is estopped from denying priority to any subrogation-based charge that was triggered by the unknown ineffectiveness of C's security. Third, more narrowly, if the later incumbrancer's security only achieved its status as a registered charge because $\mathrm{C}$ had consented to its registration ${ }^{74}$ under the mistaken assumption that it would be subordinate to C's registered charge-and therefore without any intention to cede priority-priority for C's security might perhaps be justified as a way of reversing the later incumbrancer's unjust enrichment at C's expense. Fourth, $\mathrm{C}$ might seek similar priority by the more indirect route of rectification, relying on the Registrar's/court's jurisdiction to "correct" a "mistake". 75

\section{(iv) Parasitic protection: continuation of X's charge's entry in the Register}

A final situation, which effectively arose in the Anfield case ${ }^{76}$ is even more challenging. Imagine that $\mathrm{C}$ is subrogated to $\mathrm{X}$ 's registered charge, which was paid off but not formally cancelled from the Register. There is no entry in the Register in $C$ 's name, which protects the priority of any interest $C$ might have vis-à-vis later registered disponees. However, does the fortuitous continuance of the entry in respect of $X$ 's charge, in $X$ 's name, change the equities? Intuitively, one might think that there could be a difference. A later registered disponee could not have legitimately assumed, based upon any inspection of the Register, that the property was unencumbered: a Register-search would have disclosed that a charge subsisted. Unless the later disponee had inquired of $\mathrm{X}$, the registered charge-holder, and was led to believe that it was an empty shell, it is not obvious that a later registered disponee would be seriously prejudiced, if it were subject to C's interest. The relevant title appeared to be encumbered, and if the later disponee indeed proceeded without inquiry, it arguably accepted the risk that it might have a subordinate interest.

How might this conclusion be reached, if desired? One obvious option is to argue for "parastic protection", by analogy to that allowed in Joseph: the priority of C's interest is protected parasitically on the enduring registered status of $X$-creditor's right. Would this nevertheless be a step too far? The subsisting entry here is not in C's name. As such, and unlike the entry in Joseph, it would not direct a person searching the Register to the person claiming the relevant, parasitically-protected right.

One advantage of this solution to Anfield-like facts is that it meets the justice of the case, without requiring any blanket recognition that C's subrogation-based interest

\footnotetext{
${ }^{72}$ This situation could in theory arise if the underlying registered title, subject to ME's charge, had been subject to a "restriction" (see LRA 2002, ss 40-47), which purported to prevent the registration of any dealing by the registered proprietor, without the consent of ME, as charge-holder.

73 Joseph [2014] EWCA Civ 28; [2014] 1 P\&CR 18.

${ }^{74}$ For explanation of this possibility, see supra, n 68. $C f$ the unsuccessful argument, based upon a mistaken consent to registration by the holder of an equitable charge "protected" by a restriction, in the more complex factual configuration involved in Barons Finance Ltd v Kensington Mortgage Co Ltd [2011] EWCA Civ 1592.

${ }^{75}$ See further infra, Part E(4).

${ }^{76}$ Anfield [2010] EWHC 2375 (Ch); [2011] 1 WLR 2414.
} 
has identical priority in all respects to X's charge-ie, as if X's registered charge remained, even where it did not. It only involves recognising the reality that where X's empty charge fortuitously remains on the Register, a third party's legitimate expectations may not be substantially defeated if C's subrogation-based right, which arose from the discharge of X's charge, is afforded parasitic priority protection. The equities look rather different if X's registered charge had been de-registered, after X was paid off, and before any later registered disposition in favour of a third party. There would then be no Register-entry suggesting that the relevant title was encumbered, in favour of $\mathrm{X}$ or $\mathrm{C}$. As a result, there would be no obvious basis for finding that a later registered disponee, who could rely on section 29, LRA 2002, should be subject to C's subrogation-based right. To enhance its priority position, C would need to rely on some highly-contestable arguments grounded on the Registrar's/court's jurisdiction to alter/rectify the Register. ${ }^{77}$

\section{E. WHAT IS THE ROLE FOR ALTERATION/RECTIFICATION?}

\section{Introduction}

The final task for this article is to examine the role for alteration/rectification of the Register in effectuating subrogation rights. ${ }^{78}$ What might $\mathrm{C}$ subrogation claimant, stand to gain from an application to have the Register altered/rectified to reflect - or give further effect to-its subrogation entitlement? This area is littered with potential traps. ${ }^{79}$ In the absence of reasoned decisions, it is necessary to return to first principles. Two basic situations require exploration: where X's charge was a merely equitable charge; and where X's charge was a registered (legal) charge. What might be achieved, in either case, within the LRA 2002's jurisdictional parameters of "bringing the register up-to-date" or "correcting a mistake"? ${ }^{80}$ The best answer is "relatively little", and certainly less than the courts sometimes seem, without analysis, to have assumed.

\section{The origin and nature of C's interest}

Where $\mathrm{C}$ has paid off an earlier equitable charge affecting D's registered title, in circumstances triggering subrogation, $\mathrm{C}$ may be entitled to an equivalent charge by subrogation. No Register entry is required to bring C's interest into being. It would arise in accordance with general principles of law and subsist "off-Register".

\footnotetext{
${ }^{77}$ See further infra, Part E(4).

${ }^{78} \mathrm{Cf}$ cases where alteration/rectification of the Register may be a trigger for subrogation, because it is the event that defeats the lender's security-expectation-eg if rectification of a forged disposition to B leads to cancellation of B's registered title, and the further consequence that the registered charge granted by B to C, to secure borrowing from C, falls away: cf Nouri v Marvi [2005] EWHC 2996 (Ch); [2006] 1 EGLR 71

${ }^{79} \mathrm{Cf}$ previously Mitchell and Watterson, [8.115-8.123].

${ }^{80}$ LRA 2002, sch 4, paras 2(1)(a), (b) (alteration pursuant to a court order) and 5(a), (b) (alteration otherwise than pursuant to a court order). For extended general discussion of the proper interpretation of these provisions, see Ruoff and Roper: Registered Conveyancing (Sweet and Maxwell, London, looseleaf) ch 46 (hereafter 'Ruoff and Roper'), and the growing academic literature, eg E Lees, "Title by Registration: Rectification, Indemnity and Mistake and the Land Registration Act 2002" (2013) 76 MLR 62; S Cooper, "Regulating Fallibility in Registered Land Titles" [2013] CLJ 341; A Goymour, "Mistaken Registrations of Land: Exploding the Myth of "Title by Registration"” [2013] CLJ 617; S Cooper, "Resolving Title Conflicts in Registered Land" (2015) 131 LQR 108.
} 
Less obviously, the position is no different, where $\mathrm{C}$ paid off an earlier registered charge affecting D's registered title. C's subrogation entitlement is the result of equity's intervention. Equity treats $\mathrm{C}$ as if $\mathrm{C}$ held $\mathrm{X}$ 's paid-off charge, although $\mathrm{C}$ does not. As such, $\mathrm{C}$ has a new and independent equitable charge that prima facie replicates X's paid-off charge. This is so, even when X's paid-off charge was a registered charge, and irrespective of whether X's paid-off charge has been deregistered or formally remains. Following this line of analysis, as where X's paid-off charge was a merely equitable charge, no entry in the Register is required to bring C's subrogation entitlement into being. It arises and subsists independently of the Register. Furthermore, the better analysis is that $\mathrm{C}$ cannot obtain a registered charge by this process of subrogation - neither X's previous registered charge, nor any new registered charge, replicating X's charge. C's only entitlement is to be treated in equity as if $\mathrm{C}$ held an equivalent charge.

If these suggestions are correct, then some courts have erred in assuming that they can order $\mathrm{C}$ to be recorded as holder of a registered charge- and a fortiori of X's registered charge - pursuant to C's subrogation entitlement. That cannot be justified in order to "bring the register up to date": that would require the false assumption that $C$ had become entitled to a registered charge. It also could not be justified on the basis that it is required to "correct" any "mistake" by the Land Registry.

One variety of "mistake" that has recently been recognised as potentially rectification-justifying under schedule 4 , is the Land Registry's "mistake" in deregistering an existing registered interest (eg a freehold/leasehold estate). ${ }^{82}$ Consistently with this, one can imagine an argument being advanced in a subrogation case that the Land Registry may have made a "mistake" in de-registering X-creditor's registered charge, which should instead have been "kept alive" for C's benefit, and that this justifies $\mathrm{C}$ becoming registered as holder of $\mathrm{X}$ 's charge. The flaws in this reasoning may be obvious. It is difficult to see how X's de-registration is a "mistake", and a fortiori, a "mistake" that should be corrected by recording someone else as holder of the relevant charge. X, the paid-off creditor, received funds in discharge of liabilities owed to it by $\mathrm{D}$. As between $\mathrm{X}$ and $\mathrm{D}$, this discharge was intended and effective. Indeed, the discharge of $\mathrm{X}$ 's rights is the very thing that justifies the generation of new rights in favour of $\mathrm{C}$, the subrogation claimant.

\section{The priority of C's interest vis-à-vis pre-existing interests}

There is also no material distinction, when it comes to the priority of C's interest visà-vis pre-existing interests, according to whether X's charge was a merely equitable charge or a registered charge. In either case, no entry in the Register is required to ensure that C's interest is effective vis-à-vis D-discharged debtor and/or subordinate incumbrancers, who held subordinate interests at the time X-creditor's equitable charge was discharged.

\footnotetext{
${ }^{81}$ See eg Ruoff \& Roper, [46.009], which adopts the commonly-held view that the statutorilyundefined ground of "correcting" a "mistake" in sch 4, LRA 2002, requires a mistake by the Land Registry, and that this might exist where the Registrar: makes an entry in the Register that he would not have made; makes an entry in the Register that would not have been made in the form in which it was made; fails to make an entry in the Register that he would otherwise have made; or deletes an entry that he would not have deleted, had he known the true state of affairs at the time of the entry or deletion.

${ }^{82}$ See esp Barclays Bankv Guy [2010] EWCA Civ 1393; [2011] 1 WLR 681; MacLeod v Gold Harp Properties Ltd [2014] EWCA Civ 1084; [2015] 1 WLR 1249.
} 
In principle, C's ability to assert rights against those parties does not depend on C's interest being a proprietary interest, which affects them in accordance with ordinary priority principles. It depends on the circumstances: (i) that those parties were previously affected by X's charge, as debtor/chargee and/or junior incumbrancer; and (ii) that, as a result of paying-off X's charge, $C$ has obtained new rights against them, as a remedy to reverse their unjust (primary and secondary) enrichments. These new rights comprise a charge prima facie inheriting the priorities of the old, and are effective vis-à-vis those parties without entry in the Register. It is not strictly necessary, therefore, in order to secure C's position vis-à-vis those parties, for $\mathrm{C}$ to have the Register altered to note the existence of its subrogation-based charge as adversely affecting the debtor/chargor's registered title and as having priority over the junior incumbrancers. At best, $\mathrm{C}$ might seek such alteration, if possible, in the interests of transparency. This would "bring the register up to date" to reflect offRegister events - ensuring that the Register accurately reflects subsequent circumstances that have adversely affected the interests of the relevant parties. Several further consequences would quite properly follow. Alteration would have to be ordered unless exceptional circumstances justified not making the alteration; ${ }^{83}$ there would be no special protection for any registered proprietor in possession; ${ }^{84}$ and no indemnity would be available under schedule 8 to the debtor/chargor and junior incumbrancer, who are adversely affected. ${ }^{85}$

\section{The priority of C's interest vis-à-vis intervening interests}

There is also, finally, no material distinction to be drawn, when it comes to the priority of C's interest vis-à-vis intervening interests arising after X's charge was discharged, according to whether X's charge was a merely equitable charge or a registered charge. In either case, C's position would be decided according to the same basic priority premises, elaborated earlier. ${ }^{86}$ They can be summarised as follows. The analysis should proceed on the basis that $\mathrm{C}$ acquired a form of equitable entitlement in rem as the relevant subrogation-justifying facts occurred. C's priority vis-à-vis later interests is determined by applying the general priority rules of the LRA 2002 regime, on that assumption. As such, C's interest should have prima facie priority vis-à-vis later interests via section 28, LRA 2002, but it would be postponed to a later registered disposition that triggered section 29, LRA 2002, unless it was relevantly "protected" at the appropriate time. In principle, the priority of C's interest can be protected directly, for the future, via a notice entered against D's registered title. Beyond this, courts may find the priority of C's interest to be protectable indirectly, via a form of "parasitic" protection, based upon some other entry in the Register, as discussed above. ${ }^{87}$ It is unclear how far they will go in this regard. Insofar as parasitic

\footnotetext{
${ }^{83}$ Land Registration Rules 2003, r 126(1), (2).

${ }^{84}$ Cf LRA 2002, sch 4, para 3(2) (court order), para 6(2) (Registrar order), a restriction which applies only to instances of "rectification", a species of "alteration" that involves the "correction" of a "mistake" in a manner that prejudicially affects the title of a registered proprietor: LRA 2002, sch 4, para 1.

${ }^{85}$ See LRA 2002, sch 8, para 1(1)(a), (b), which provides for an indemnity if a person suffers loss by reason of "rectification" of the Register, or by reason of a mistake whose correction would involve "rectification" of the Register. An alteration that merely brings the Register up-to-date, and does not amount to "rectification" (see supra, n 78), does not trigger this right to an indemnity: eg Ruoff \& Roper, [46.006].

${ }^{86}$ See supra Part D(2)(a), (b).

${ }^{87}$ See supra Part D(2)(b)(ii), (iii) and (iv).
} 
protection is recognised, it would certainly seem appropriate to allow "alteration" of the Register to reflect the "truth" and bring the register "up-to-date". This might involve replacing the entry that affords parasitic protection, with a notice that directly refers to and protects C's subrogation entitlement - eg amending a relevant notice to refer to C's subrogation-based interest, rather than any interest which was previously directly protected in that manner.

Ultimately, the most difficult question is whether $\mathrm{C}$ could ever achieve, via alteration/rectification of the register, priority which $C$ could not otherwise claim in accordance with the general priority rules of the LRA 2002 regime, or other principles of law ( $e g$ some priority arrangement with D's other creditors). In particular, could C, via the court's/Registrar's jurisdiction to alter/rectify the Register, obtain priority visà-vis an intervening interest to which C's interest would otherwise be subject?

In practice, this would probably involve C seeking "rectification" to achieve priority over a later party who seeks to rely on section 29 LRA 2002's priority promise. Any amendment with that effect would almost certainly need to be justified as a form of "rectification", appropriate to "correct" a "mistake" in the Register. It would also raise the thorny question, addressed in MacLeod v Gold Harp Properties $L t d,{ }^{88}$ whether rectification can re-order priorities retrospectively, or at least prospectively from the date of any rectification order. It is impossible at this stage to predict the exact form in which such an argument might be raised. But some testing examples can be contemplated.

A simple configuration would be where $\mathrm{C}$ sought a notice to protect the priority of its subrogation entitlement, and the Land Registry entered the notice against the wrong title. $\mathrm{C}$ could no doubt seek alteration of the Register, to correct this errorremoving the notice from the wrong title, and entering it against the correct title. Greater difficulty might arise if, prior to this correction in the Register, there was an intervening registered disposition in favour of a third party which attracted section 29, LRA 2002. Prima facie, the interest created by that registered disposition would take free of C's interest, which at the relevant time, was not relevantly protected in the Register or otherwise overriding. However, the Gold Harp ${ }^{89}$ case recently suggests that a court might, as part of the process of "correcting" the mistake, effectively reorder priorities - at least prospectively, from the date of the court order. On that controversial assumption, $\mathrm{C}$ might seek an adjustment to the Register that would afford its entitlement priority vis-à-vis the later registered disposition.

More complex configurations can be envisaged. For example, imagine that $\mathrm{C}$ has been granted a forged charge, which is registered, and that the money $\mathrm{C}$ has loaned has been used to pay off X-creditor's secured loan. It later turns out that C's charge is ineffective. The Registrar should not have registered the forged charge; the appropriate entry would instead be a notice to protect C's subrogation-based entitlement, generated in the same circumstances. It is harder here to say that the Registry has made a "mistake" in omitting to make an alternative notice entry in respect of the subrogation-based charge, which might be appropriately "corrected" by making such an entry. ${ }^{90}$ However, even if — which seems unlikely-that leap could be

\footnotetext{
${ }^{88}$ Gold Harp [2014] EWCA Civ 1084; [2015] 1 WLR 1249.

${ }^{89}$ Ibid. For analysis, see eg A Goymour, "Resolving the Tension Between the Land Registration Act's 'Priority' and 'Alteration' Provisions" [2015] Conv 253; E Lees, "Rectification of the Register Prospective or Retrospective" (2015) 78 MLR 361.

${ }^{90}$ It would require a rather expansive reading of sch 4 to say that there may be a qualifying "mistake", in failing to enter such a notice, either (a) at the the time when the forged charge was first registered, or (b) at any later point when the previously-registered forged charge is deleted from the Register. It
} 
made, difficult questions would then arise if there was an intervening registered disposition that attracted section 29 LRA 2002. How might that situation be resolved? One solution would be to say that in this case, the priority of C's subrogation-based entitlement is protected parasitically, via the entry in respect of its forged charge - a solution that does not require any strained reading of the rectification jurisdiction, but that would deny the third party the benefit of any indemnity. An alternative would be to follow Gold Harp, and allow for the possibility that rectification might be ordered to enter a notice of C's subrogation-based entitlement against D's registered title, and in a manner that gives C's entitlement, at least for the future, priority over the intervening third party disposition.

Some of this reasoning is clearly strained. Furthermore, it will only sporadically improve C's priority position. Its viability requires a relevant qualifying act/omission of the Land Registry, presumably in response to an application made to it, which can be regarded as "mistaken". The examples already given are easy illustrations. In each case, the Registry made an inappropriate entry-registering a notice against the wrong title, or registering a forged charge when it should have made an entry in respect of the subrogation-entitlement that arose on the same facts. Other problematic financing transactions will not exhibit this feature. Often, $\mathrm{C}$ is granted an interest that is, at least at the time of registration, a duly-registered charge. The only problem is that $\mathrm{C}$ receives something other than $\mathrm{C}$ expected, from the point of view of priority-eg because $\mathrm{C}$ finds its charge is encumbered by a pre-existing beneficial interest, whose priority is protected by the occupation of the interest-holder. ${ }^{91}$

One last point needs to be made. One possible benefit of an expansive view of rectification as a mechanism for improving C's priority position-relative to other mechanisms such as "parasitic protection"-is that if C's enhanced priority vis-à-vis later interests can be attributed to the rectification process, this can trigger an indemnity for those adversely affected by rectification. ${ }^{92} \mathrm{C}$ might then obtain priority, and the Land Registry would foot the bill for the prejudice that results to third parties, except insofar as the third party was fraudulent or carelessly responsible for the problem. ${ }^{93}$

\section{F. CONCLUSION}

Close analysis of the operation of subrogation rights within the LRA 2002 regime reveals three problems that future courts will need to be careful to avoid.

First, the courts, and potentially the Land Registry, run the risk of unthinkingly affording subrogation-claimants rights that may be unjustified - being more extensive than are strictly warranted, once the jurisdictional basis of subrogation is understood. We may not recognise the difference if the paid-off security interest is equitable (an equitable charge/unpaid vendor's lien). But we may potentially notice a difference, if the paid-off security is legal (a registered legal charge). Courts seem persistently to misunderstand, or under-analyse, what the claimant's rights should be in this setting.

\footnotetext{
would require an assumption that the Registrar at either point, without any request/application, and potentially without sufficient information as to the underlying facts, should then have entered a notice to protect the resulting equitable subrogation-based entitlement.

${ }^{91}$ LRA 2002, sch 3, para 2; and see eg Karasiewicz [2002] EWCA Civ 940 (involving equivalent provisions of the LRA 1925).

${ }_{92}^{2}$ LRA 2002, sch 8, para 1(1)(a).

${ }^{93}$ LRA 2002, sch 8, para 5.
} 
Second, and relatedly, the proper resolution of priority disputes has been inadequately analysed. The preferable approach, which is justifiable in terms of the Banque Financière analysis and does least violence to the integrity of the LRA 2002 framework, involves the assumption that one must distinguish two key priority questions - the status of C's subrogation entitlement vis-à-vis pre-existing third party rights, that pre-dated the discharge of X-creditor's security, at C's expense; and the status of C's subrogation entitlement vis-à-vis subsequent third party rights, which arise only after event. This analysis steers a mid-course between early decisions like Omar-which seemed to say C's subrogation entitlement has nothing to do with unjust enrichment - and decisions like Anfield - which seem to imply that unjust enrichment has a role in explaining the priority that a subrogation claimant is afforded over all third party rights, whether pre-existing, or subsequent. The key assumption is that a proprietary right/inchoate proprietary right, of equitable origin, is immediately generated to reverse unjust enrichment, but that after that, that the relevant rights behave like standard property rights - ie a third party who subsequently acquires an interest is affected only if that third party would be affected in accordance with the standard priority rules applicable to competitions between interests of the relevant quality, in the relevant subject-matter.

Thirdly, misunderstanding of these first two points can also produce some unwarranted conclusions when it comes to understanding the role for alteration or rectification. This is true whether we have a previously vacated registered charge or a subsisting but still registered charge. In short, it threatens to muddy the answer to the question, what can an application for Register-alteration or -rectification achieve? 